\title{
Use of Higher Ethylene Generating Fruits for Ripening as an Alternative to Ethylene
}

\author{
PRASHANTA POKHREL* \\ Department of Food Technology and Quality Control, Kathmandu, Nepal
}

*Corresponding author: prashantapokhrel@hotmail.com

Every fruit has its own best eating quality upon natural ripening. But not all fruits are allowed to ripen on the plant. Ripe fruits cannot withstand the postharvest handling system when shipped long distance. They are likely to become soft and mealy with insipid flavour after traveling long. Climacteric fruits are often picked at the maturity stage so that they can withstand the postharvest handling hazards. Likewise to ripen them, ethylene gas is generally used. In most of the countries calcium carbide is used as a source of acetylene (alternative to ethylene) for ripening. However it has been banned in many countries including Nepal. And for those who produce organic fruits, natural ripening can bring a physico-chemical hazard during postharvest handling. Ripe climacteric fruits produce ethylene gas in amounts higher than the threshold level required to induce the ripening process of such fruits. So as a solution to the above problem, ripe fruits can be taken to ripen the mature climacteric fruits.

Keywords: acetylene, carbide, ethylene, threshold level

\section{Introduction}

Fleshy fruits undergo a natural stage of development known as ripening. This occurs when the fruit has ceased growing and is said to be mature. With a few exceptions all fruits attain optimal eating quality when allowed to ripen on the plant. Some fruits are, however, picked at a mature but unripe stage of development so as to allow them to withstand post-harvest handling conditions when shipped over long-distances. Maturity indices for such fruits are based on a compromise between those indices that would ensure the best eating quality to the consumer and those that provide flexibility in marketing (Simson and Straus, 2010).

Non-climacteric fruits are incapable of continuing their ripening process once removed from the plant while climacteric fruits can be harvested at the mature stage and allowed to ripen off the plant. Climacteric and nonclimacteric fruits respond differently to external ethylene (Belitz et al., 2009). Non climacteric fruits produce very small quantities of ethylene $\left(\mathrm{C}_{2} \mathrm{H}_{4}\right)$ and do not respond to ethylene treatment except in terms of de-greening; these should be picked when fully-ripe, if good flavor quality is to be ensured. Climacteric fruits produce comparably larger quantities of ethylene which is associated with their ripening, and undergo more rapid and uniform ripening upon exposure to ethylene (Simson and Straus, 2010).

\section{Agents used for ripening fruits}

In commercial fruit production and marketing, artificial ripening is used to control the rate of ripening, thus enabling transport and distribution to be carefully planned (Simson and Straus, 2010).

Ethylene is the most active ripening agent (Rahman, 2007). Similarly ethephon/ethrel is also used in many places to ripening fruits. It is acidic in water solution and liberates ethylene in neutral to basic medium generally above $\mathrm{pH}$ 5. The amount of ethylene released depends on the fruit $\mathrm{pH}$ and relative humidity. (Siddique and Dhua, 2010). Acetylene, generated by mixing water with calcium carbide $\left(\mathrm{CaC}_{2}\right)$ salt, can also be used as a ripening agent; however, it is 100 times less effective compared to ethylene (Rahman, 2007). Thus acetylene accelerates ripening but only at substantially higher concentrations. The activity of propylene is only $1 \%$ of that of ethylene. (Belitz et al., 2009). Another simple method of initiating ripening is to light a smoky fire in the ripening room. This can produce various gases, including acetylene, ethylene and carbon monoxide, which will initiate ripening (Thompson, 2003).

In some places of Nepal, indigenous plant materials like 'asuro', 'dhurseli', 'fresh rice straw', are also used for ripening fruits like banana. These plant materials are used at about $10 \%$ of the amount of fruits and left covered for a week to ripen. But their efficiency is very less in comparison to ethylene gas (Khatiwada, 2005). Hence to ripen quickly at the destination market, a small amount of $\mathrm{CaC}_{2}$ is wrapped in a paper packet and kept near a pile 
Pokhrel: J. Food Sci. Technol. Nepal, Vol. 8 (84-86 ), 2013

of box of fruits. Reaction occurs between $\mathrm{CaC}_{2}$ and the moisture content of air to produce acetylene gas. In case of banana, ripening starts within 24-48 hours, depending on the ambient temperature. Calcium carbide is widely used in Nepal, India, Pakistan, Bangladesh, and other countries. (Siddique and Dhua, 2010).

\section{Negative aspects of Carbide}

According to Food Regulation, 1970 (Nepal), the production, sell or holding of fruits ripened artificially from carbide is prohibited. Calcium Carbide is not regarded as GRAS. $\mathrm{CaC}_{2}$ contains traces of arsenic and phosphorus hydride. Acetylene prepared from $\mathrm{CaC}_{2}$ also contains phosphine and some arsine upto 95 and $3 \mathrm{ppm}$ respectively. A strong reactive chemical, $\mathrm{CaC}_{2}$ has carcinogenic properties. Acetylene gas is flammable and explosive even in a low concentration compared to ethylene. Acetylene is poisonous to humans above $10 \%$ concentration. Vomiting, diarrhea, burning sensation of the chest and abdomen, thirst, weakness are the early symptoms of arsenic or phosphorus poisoning in humans. Eating artificially ripened mangoes causes stomach problems (Siddique and Dhua, 2010).

Exposure to ethylene (1 ppm) can reduce the postharvest life of many fruits and vegetables by hastening the onset and increasing the rate of senescence, softening, and loss of green color (Rahman, 2007).

\section{Ripe climacteric fruits as a source of ethylene}

Ethylene, a natural phytohormone, produced by some fruits upon ripening promotes additional ripening of produce exposed to it (Gerald et al., 2006). Initiation of ripening occurs when a threshold level of ethylene is reached in the cells of the fruits (Thompson, 2003). This gaseous compound increases membrane permeability and thereby probably accelerates metabolism and fruit ripening. Fruits like avocado, banana, mango, pear and tomato produce $500,40,3,40,35 \mu \mathrm{g} / 1$ ethylene at the climacteric maximum (Belitz et al., 2009), while the threshold level of ethylene for fruits like avocado (var. Choqeutte), banana (var. Lacatan, var. Silk fig), lemon (var. Frot meyors), mango (var. kent), tomato (var. VC243-20) ranges from 0.1 to $0.5 \mathrm{ppm}$ respectively (Reid, 1985).

Similarly, the threshold level for degreening of the rind is $1 \mathrm{ppm}$, while $2.5 \mathrm{ppm}$ is required to trigger the ethylenedependent component of the softening process. The saturating level of ethylene for all these events is less than $5 \mathrm{ppm}$, which is far lower than the internal ethylene concentrations found in the fruit at the climacteric peak (around $100 \mathrm{ppm}$ ). Detachment of the fruit influences the development of respiratory climacteric (Pech et al., 2011).

\section{Application}

As the ethylene production in ripened fruits is far higher than the threshold level; ripened fruits can be placed along with some unripe matured fruits (in a ratio from 1:20 in open and in a ratio of 1:100 in a closed environment) to initiate ripening. Alongside some important conditions that should be considered during the process are temperature, relative humidity, concentration of $\mathrm{CO}_{2}$ and adequate air circulation. They directly regulate the physiological reaction inside a fruit. Hence, these parameters should be varied according to commodity.

According to Vaclavik and Christian (2008) a simple technique for ripening fruit at home is to place unripened fruit in a closed paper bag in order to trap ethylene gas and speed up desirable ripening. The concentration of ethylene and treatment duration to achieve the desired effect will vary with the product. For most products, the threshold concentration is $0.1 \mathrm{ppm} \&$ and the maximum effect is achieved at $10 \mathrm{ppm}$ or less. However, some treatments may use up to $100 \mathrm{ppm}$ to adjust for leaky rooms (Chakraverty et al.,2003).

Organic fruits and vegetables generally are left to ripen on themselves, but fruits from a single lot do not ripen at a time. In this case ethylene from ripe fruits could be a good choice. And this process would be more consistent with the principles of organic production including environmental friendliness.

\section{Problems about the ethylene generated from ripe fruits}

The ethylene level found to accumulate around produce in markets is in the range $0.06-1.45 \mu \mathrm{l}$ per liter, suggesting that premature ageing occurred in all non-climacteric crops during normal marketing (Thompson, 2003). Once initiated, ripening is a one-way process and the beneficial aspects of ethylene for generating a high-quality product can soon be outweighed by its propensity to stimulate over-ripening and decay (Barry and Giobannoni, 2007). Similarly higher ethylene generating fruits when used for ethylene production generally overripe, thus decrease their usefulness to some extent. In the similar manner, higher respiration rates increase the temperature thus increasing production and loss of water. Water loss or dehydration means a loss in fresh weight. This in turn affects the appearance, texture, and in some cases the flavor. Water loss also affects crispiness and firmness (Simon and Straus, 2010). 
Pokhrel: J. Food Sci. Technol. Nepal, Vol. 8 (84-86 ), 2013

\section{Conclusions}

Ethylene is very important hormone that regulates the development and ripening process of fruits. In our country though use of carbide for ripening is banned, it is still used by businessmen. Ethylene cylinders are not available. The level of ethylene present in ripe climacteric fruit is more than sufficient for inducing the major ripening-associated events such as softening and colour changes. Hence this method can be suggested for fruit vendor's in our country as an alternative to non GRAS harmful calcium carbide.

\section{References}

Barry C.S. and Giobannoni J.J. (2007). Ethylene and Fruit Ripening. Journal of Plant Growth Regulation (2007)26:143-159.

Belitz H.D., Grosch W. and Schierberle P. (2009). Food Chemistry. $4^{\text {th }}$ revised and extended Edition. Springer Publications. USA.

Chakraverty A., Mujumdar A.S., Vijaya Raghavan G.S., Ramaswamy H.S. (2003). Handbook of Postharvest Technology Cereals, Fruits, Vegetables, Tea and Spices. Marcel Dekker, Inc. USA.

Food Regulation (1970). Chapter 7 ... and Matters to be Observed by Food seller. Rule no 19(d). Nepal Government.

Gerald M.S., James R.G., Ahmed E. Y. (2006). Microbiology of Fruits and Vegetables. CRC press. Taylor and Francis Group. UK.

Khadiwada B.P (2005). Ripening regulation of banana (Musa sapientum L.) cv. Malbhog using chemicals and indigenous plant materials. Msc thesis. Department of horticulture. Institute of Agriculture and Animal Science. Rampur, Chitwan, Nepal. 88 pp.

Pech J.C. El-Yahyaoui F., Bernadac A., Latché A., Flores B. and Romojaro F. (2011). Role of ethylene on various ripening pathways and on the development of sensory quality of Charentais cantaloupe melons. In http://oatao.univ-toulouse.fr/1451/1/Pech 1451. pdf. Assessed March 28, 2012.

Rahman M.S. (2007) Handbook of Food Preservation. $2^{\text {nd }}$ Edn. CRC Press. USA.

Reid M. S. (1985). Ethylene in Postharvest Technology. In: Postharvest Technology of Horticultural Crops. Kadar, A. A., Kasmire R.F., Micthell F. G., Reid, M. S, Sommer N. F., Thompson J. F. (Special publication 3311). Cooperative Extension. Univerisity of California. Division of Agriculture and Natural Resources. US. pp 68-74.

Siddique Md. W. and Dhua R. S. (2010) Eating artificially ripened fruits is harmful. Current Science, vol. 99, No.12, 25 December, 2010. Pp 1664-1668. Published by the Current Science Association in collaboration with the Indian Academy of Sciences.

Simson S.P. and Straus M.C. (2010) Post Harvest Technology of Horticultural Crops. Oxford Book Company, Jaipur, India.

Thompson A. K. (2003). Fruits and Vegetables Harvesting, Handling and Storage. $2^{\text {nd }}$ Edn. Blackwell Publishing. UK. pp 86-95

Vaclavik V. A. and Christian E. W. (2008). Essentials of Food Science. 3rd Edn. Springer Publications. USA. 